\title{
R Factors from Proteus rettgeri
}

\author{
By J. N. COETZEE \\ Department of Microbiology, University of Pretoria, Republic of South Africa \\ NAOMI DATTA* AND R. W. HEDGES \\ Department of Bacteriology, Royal Postgraduate Medical School, \\ Hammersmith Hospital, London, WI2 oHS
}

(Received 28 March 1972; revised 23 May 1972)

\section{SUMMARY}

Of 12 R factors transferred from wild strains of Proteus rettgeri to Escherichia coli $\mathrm{KI} 2$, all were $f^{-}$. Five were of the $\mathrm{N}$-compatibility group; three belonged to a newly defined group T, of which Rts I is the prototype; one belonged to group W. The other three constituted at least one compatibility group, not previously described. The replication of two of the T plasmids, like that of Rts I, was temperature sensitive. This set of $\mathrm{R}$ factors is significantly different from those derived from bacteria of other genera.

\section{INTRODUCTION}

Plasmids transferable to Escherichia coli have been identified in several naturally occurring Proteus strains (Falkow, Wohlhieter, Citarella \& Baron, I964; Datta \& Kontomichalou, I966; Smith \& Armour, I966; Mitsuhashi, Hashimoto, Egawa, Tanaka \& Nagai, I967; Terawaki, Takayasu \& Akiba, I967; Naide, Kawamura, Makino, Tamura \& Watanabe, 1967; Dobozy \& Hammer, 1968; Pitton, 1970; Poty, Goze \& Gagnon, 1971; Odakura, Tanaka \& Mitsuhashi, 197I). R factors of several different compatibility groups can be transferred from $E$. coli to members of the Proteus tribe. However, transfer of I-like plasmids did not occur at a detectable frequency and the rate of transfer of several other types of plasmid was lower than that in crosses between strains of E. coli (Datta \& Hedges, 1972a).

Strains of Proteus rettgeri are often resistant to a broader spectrum of antibiotics than other members of the group (Odakura et al. I97I). We decided to look for R factors in this species, to determine their compatibility properties and the extent to which the Proteus $\mathrm{R}$ factor set resembles sets of other genera.

\section{METHODS}

Bacteria. One hundred and forty-four strains of Proteus rettgeri were isolated during 1967 from human faeces in Pretoria. They all had the phenotypic characteristics of $P$. rettgeri. Many strains were resistant to $100 \mu \mathrm{g} / \mathrm{ml}$ tetracycline, ampicillin, streptomycin and chloramphenicol. Resistance to sulphonamides varied and only 16 strains were resistant to $40 \mu \mathrm{g} / \mathrm{ml}$ of kanamycin. In addition, one $\mathrm{R}$ factor, $\mathrm{R} 7 \mathrm{~K}$, derived from a strain of $P$. rettgeri isolated in Athens, was received from Dr P. Kontamichalou (Kontomichalou, I97I).

Escherichia coli $\mathrm{KI} 2$ strains: J53 $\mathrm{F}^{-}$lac ${ }^{+}$, pro, met (Clowes \& Hayes, I968); J53-I, a nalidixic acid-resistant mutant of $\mathrm{J} 53 ; \mathrm{J} 53-2$, a rifampicin-resistant mutant of $\mathrm{J} 53 ; \mathrm{J} 62 \mathrm{~F}^{-}$lac, pro,

* To whom reprint requests should be addressed. 


\section{Table I. 'Standard' $R$ factors used in tests for compatibility}

\begin{tabular}{|c|c|c|c|c|}
\hline Factor & $\begin{array}{l}\text { Compati- } \\
\text { bility } \\
\text { group }\end{array}$ & $f i$ & $\begin{array}{l}\text { Resistance and } \\
\text { restriction } \\
\text { determinants* }\end{array}$ & Reference \\
\hline RI-I $\dagger$ & F II & + & ASCSu & Hedges \& Datta (1972) \\
\hline $\mathrm{R} \mathrm{I} d r d \mathrm{I} 6 \div$ & F II & - & $\mathrm{K}$ & Frydman \& Meynell (1969) \\
\hline $\mathbf{R}_{3} 86$ & F I & + & $\mathrm{T}$ & Dennison (1972) \\
\hline RI 24 & F IV & + & $\mathbf{T}$ & Hedges \& Datta (1972) \\
\hline R64 & I & - & ST & Lawn, Meynell, Meynell \& Datta (1967) \\
\hline RI44 & I & - & TK & Lawn et al. (1967) \\
\hline $\mathrm{R}_{46}$ & $\mathbf{N}$ & - & ASTSu & Datta \& Hedges (I97I) \\
\hline Ri5 & $\mathbf{N}$ & 一 & SSuM $h s p$ II & Datta \& Hedges (1971) \\
\hline R269 N-I & $\mathbf{N}$ & - & ASTK $h s p$ II & Hedges (1972) \\
\hline RP4 & $\mathrm{P}$ & - & ATK & Datta et al. (197I) \\
\hline RP4-4§ & $\mathbf{P}$ & - & AT & \\
\hline S-a & W & - & SCKSu & Hedges \& Datta (1971) \\
\hline RA3 & W & - & $\mathrm{SCSu}$ & Hedges \& Datta (I97I) \\
\hline R388 & W & - & SuTp & Datta \& Hedges (1972 $b$ ) \\
\hline RAI & . & - & $\mathrm{TSu}$ & Hedges \& Datta (197I) \\
\hline $\mathbf{R}_{300 \|}$ & . & - & $\mathrm{SSu}$ & Lawn et al. (1967). \\
\hline
\end{tabular}

* Symbols designate resistance to: A, ampicillin: S, streptomycin; T, tetracycline; C, chloromphenicol; K, kanamycin; Su, sulphonamides; M, mercury salts; Tp, trimethoprim.

$\uparrow$ Spontaneous segregant of RI, lacking K-resistance.

\$ Mutant of RI : constitutive pilus synthesis and lacking all resistances except $\mathrm{K}$-resistance.

$\S$ Spontaneous segregant/mutant of RP4, lacking K-resistance.

|| Factor not assigned to any compatibility group yet defined.

his, trp (Clowes \& Hayes, I968); J62-I, a nalidixic acid-resistant mutant of $\mathrm{J} 62$; HfrC met (Clowes \& Hayes, I968). Salmonella typhimurium LT2, SL329 trp. Klebsiella aerogenes B9, a wild, drug-sensitive strain.

Phages. MS 2 (Davis, Strauss \& Sinsheimer, I96I). $\lambda$ vir (Jacob \& Wollman, I964).

$R$ factors. Standard $\mathrm{R}$ factors are listed in Table $\mathrm{I}$. $\mathrm{R}$ factors transferred from Proteus rettgeri strains are listed in Table 2.

Media. Nutrient broth was Oxoid No. 2 (CM 67); nutrient agar was the same solidified with $\mathrm{I} \cdot 2 \%$ New Zealand agar; MacConkey agar was Oxoid $\mathrm{CM}_{7} \mathrm{~b}$. Minimal agar salts was as described in Clowes \& Hayes (1968).

Transfer of $R$ factors. Methods were as described by Datta, Hedges, Shaw, Sykes \& Richmond (197I) and Datta \& Hedges (1972a).

Compatibility of $R$ factors. Relative frequencies of $\mathrm{R}$ transfer by conjugation (in mixtures incubated for $\mathrm{I} h$ ) into a strain of KI 2 with and without a second plasmid under test were determined. This gave a measure of exclusion (Meynell, Meynell \& Datta, I968). Recipient colonies were purified by restreaking on MacConkey agar containing the appropriate drug (and $5 \%$ lysed horse blood, where the drug was sulphonamide or trimethoprim) and tested for resistance markers of each $\mathrm{R}$ factor, resident and newly acquired. Where both factors were present, a clone was grown overnight in drug-free broth, plated on non-selective medium and 20 colonies tested for the continued carriage of both factors. $\mathrm{R}$ factors transferred from Proteus rettgeri to Escherichia coli $\mathrm{KI} 2$ were tested in this way against appropriate 'standard' $\mathbf{R}$ factors, listed in Table $\mathrm{I}$, and against one another.

Transfer from 'doubles'. Where resistance markers of both donor and recipient cultures were identified in J53 cultures after transfer, the 'double' was tested to see whether the two plasmids were transferable separately or always together. A clone was grown in broth and used as donor in a second mating with $\mathrm{J} 62(\mathrm{R}-)$ as recipient. Mixtures were plated on 
Table 2. $R$ factors from Proteus rettgeri

$\begin{array}{ccllc}\begin{array}{c}\text { Proteus } \\ \text { rettgeri }\end{array} & \text { R factor } & f & \begin{array}{c}\text { Characters } \\ \text { determined } \\ \text { by R factor }\end{array} & \begin{array}{c}\text { Compatibility } \\ \text { group }\end{array} \\ 55 & \text { R390 } & - & \text { ASSpTCSu } h s p \text { II } & \text { N } \\ \text { I07 } & \text { R39I } & - & \text { K } & \text { J } \\ \text { I05 } & \text { R392 } & - & \text { K } & ? \text { J } \\ \text { I22 } & \text { R394 } & - & \text { AK } & \text { T } \\ \text { I34 } & \text { R395 } & - & \text { ASSpTCSu } h s p \text { II } & \text { N } \\ \text { I35 } & \text { R396 } & - & \text { ASSpTCSu } h s p \text { II } & \text { N } \\ \text { I49 } & \text { R397 } & - & \text { K } & \text { J } \\ \text { I69 } & \text { R398 } & - & \text { ASSpTCSu } h s p \text { II } & \text { N } \\ \text { I37 } & \text { R400 } & - & \text { ASSpTCSu } h s p \text { II } & \text { N } \\ \text { I48 } & \text { R40I } & - & \text { AS } & \text { T } \\ \text { I75 } & \text { R402 } & - & \text { ASSp } & \text { W } \\ \text { 7KR } & \text { R7K } & - & \text { AS } & \text { W }\end{array}$

The symbol $\mathrm{Sp}$ indicates spectinomycin resistance. Others as in Table $\mathrm{I}$.

selective media to measure the frequency of transfer of resistance genes from either plasmid. Recipient clones ( 20 from each selective medium) were purified and tested for the presence of selected and unselected resistance markers.

$f i$ character. $\mathbf{R}$ factors were transferred to HfrC. An undiluted lysate of phage MS 2 (titre approximately $\mathrm{I}^{11}$ plaque-forming units $/ \mathrm{ml}$ ) was spotted on the $\mathrm{R}^{+}$culture. Visible lysis indicated that the plasmid was $f^{-}$.

Restriction of phage $\lambda$ vir. Phage $\lambda$ vir lysates of $\mathrm{J}_{53}$ and $\mathrm{J}_{53}\left(\mathrm{~N}_{3}\right)$ were plated in agar layer on nutrient agar plates with $\mathrm{J} 53$ or $\mathrm{J} 53$ carrying the $\mathrm{R}$ factors to be tested and the plaques counted. The concentration of phage was chosen to allow plaque counts to be made on restricting and non-restricting cultures (Table 4).

Segregants of $R 390$. Spontaneous segregants, sensitive to streptomycin, tetracycline or chloramphenicol, were isolated by replica plating. Segregants sensitive to sulphonamides appeared as small colonies on nutrient agar containing $5 \%$ lysed horse blood and $25 \mu \mathrm{g}$ sulphadimidine $/ \mathrm{ml}$. Approximately 10000 colonies were examined for loss of resistance markers.

\section{RESULTS}

Phenotypic characters conferred on J62-I by $R$ factors from Proteus rettgeri

$\mathrm{R}$ factors were transferred from Proteus rettgeri to Escherichia coli KI 2 J62-2 and thence to other lines of KI 2 to test their $f i$ character and their compatibility with other R factors. All I 2 $\mathrm{R}$ factors were $f^{-}$. Some belonged to previously defined compatibility groups. Others were used to define new groups. Evidence for their classification by compatibility is given below. Their characters are summarized in Table 2.

$R 391, R 392$ and $R 397$

Three of the R factors, R39I, R392 and R397, conferred resistance to kanamycin only. All three were transferred between strains of $\mathrm{K} I 2$ at low frequency. Each co-existed stably with standard R factors of all compatibility groups (Table I). Results are shown in Table 3.

$R 390, R 395, R 396, R 398$ and $R 400$

Five $\mathrm{R}$ factors, indistinguishable from one another, conferred resistance to ampicillin, streptomycin/spectinomycin, tetracycline, chloramphenicol and sulphonamide. They carried 
Table 3. Transfer and compatibility of $R 39 \mathrm{I}$

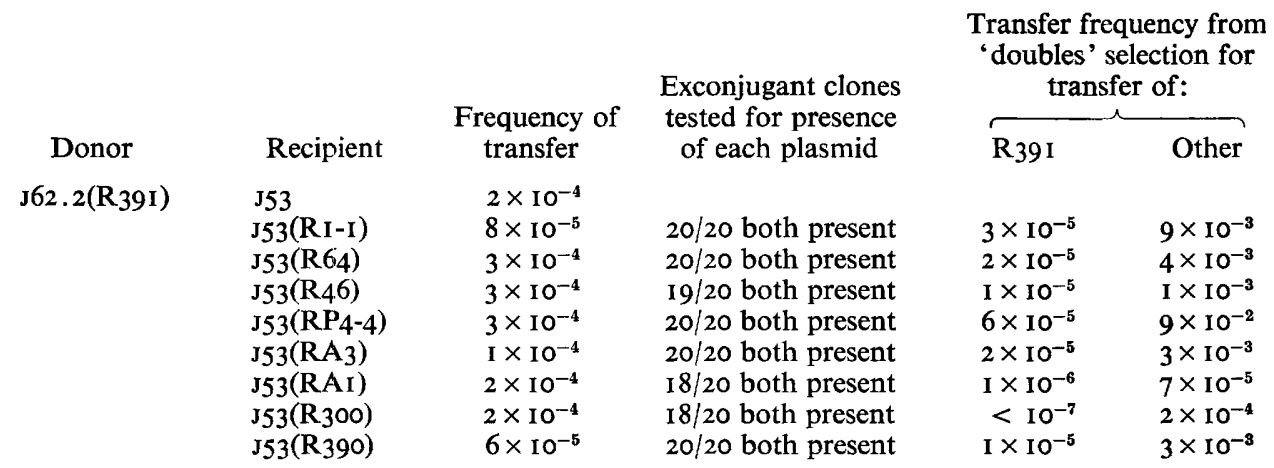

Matings were made in parallel, in conditions described in the text. Frequency of transfer was calculated per donor cell. Results are presented in sequence from left to right. Both $\mathrm{R}$ factors were stable in each 'double'. From each 'double' the other plasmid was transferred independently of R39I. Figures for R392 and R397 were very similar to those above.

the determinant for host specificity pattern II, hsp II (Bannister \& Glover, I968; Hedges, I972) (Table 4) and belonged to compatibility group N (Table 5) (Datta \& Hedges, I97I). Six classes of spontaneous segregants of $R_{390}$ were identified. The frequency of loss of one or more resistance marker was approximately $\mathrm{IO}^{-3}$. From the characters of the segregants it is possible to construct a deletion map of R390 (Fig. r).

R 390-3, a non-transmissible segregant, was shown still to have the compatibility of the $\mathrm{N}$ group, since it was always eliminated by the introduction of R I5. J62 (R390-3) was used as a recipient in matings with $\mathrm{J}_{53}(\mathrm{RAI})$ and $\mathrm{J}_{53}(\mathrm{R} 300)$, standard $\mathrm{R}$ factors which could not be detected in the presence of wild-type R390. R390-3 was compatible with RAI and R300.

The penicillinase determined by R390 was examined by Drs J. T. Smith and J. W. Dale. It had no appreciable activity against oxacillin.

\section{$R 40 \mathrm{I}$}

R40 gave resistance to ampicillin and streptomycin (but not spectinomycin). It was not excluded by, and co-existed stably with, all the standard $\mathrm{R}$ factors. As with Rts I (Terawaki et al. 1967), the replication of R40I was temperature sensitive. We therefore tested the compatibility of these two plasmids. Transfer of R4OI into a strain carrying Rts I resulted in the elimination of Rts I from 17 of 20 clones tested. The other three clones were resistant to ampicillin, streptomycin and kanamycin (i.e. had all the antibiotic resistance markers of both plasmids). That they carried recombinant plasmids was indicated by the coincident loss of all resistance markers during growth at $43{ }^{\circ} \mathrm{C}$ (Table $6 a, b$ ) and by the fact that, when they were used as donors, all three resistance genes were transferred together, no matter which drug was used for selection. The replication of R4OI was temperature sensitive not only in Escherichia coli $\mathrm{KI} 2$ but also in Klebsiella aerogenes 89 and in Salmonella typhimurium LT2 (Table $6 c$ ). Proteus rettgeri $\mathrm{I} 48$ failed to grow at $43^{\circ} \mathrm{C}$, so the temperature-sensitivity of R40 I could not be tested in its original host.

\section{$R 394$}

R394 conferred resistance to ampicillin and kanamycin. In the first set of experiments this plasmid appeared incompatible with $\mathrm{R}_{46} 6$ and $\mathrm{R} 390$ and therefore to be an N plasmid. But in subsequent experiments $\mathrm{R}_{394}$ and various N plasmids (including R46 and R390) 
Table 4. Restriction of phage determined by $R$ factors

\begin{tabular}{lrc} 
& $\begin{array}{c}\text { No. of plaques from uniform } \\
\text { dose of } \lambda \text { vir grown on: }\end{array}$ \\
\cline { 2 - 3 } Culture & $\mathrm{J} 53$ & J53(N3) \\
J53 & 374 & 40 \\
J53(R15) & 20 & 44 \\
J53(R390) & 9 & 42 \\
J53(R391) & 427 & 33 \\
J53(R392) & 468 & 39 \\
J53(R394) & 470 & 44 \\
J53(R395) & 16 & 40 \\
J53(R396) & 22 & 56 \\
J53(R397) & 488 & 37 \\
J53(R398) & 16 & 33 \\
J53(R400) & I 8 & 46 \\
J53(R40I) & 421 & 43 \\
J53(R402) & 418 & 39 \\
J53(R7K) & 406 & $4 I$
\end{tabular}

Table 5. Transfer and compatibility of $R 390, R 395, R 396, R 398$ and $R 400$

\begin{tabular}{|c|c|c|c|c|c|}
\hline \multirow[b]{2}{*}{ Donor } & \multirow[b]{2}{*}{ Recipient } & \multirow{2}{*}{$\begin{array}{l}\text { Frequency of } \\
\text { transfer }\end{array}$} & \multirow{2}{*}{$\begin{array}{l}\text { Exconjugant clones } \\
\text { tested for presence } \\
\text { of each plasmid }\end{array}$} & \multicolumn{2}{|c|}{$\begin{array}{l}\text { Transfer frequency from } \\
\text { 'doubles' selection for } \\
\text { transfer of: }\end{array}$} \\
\hline & & & & $\mathrm{R}_{390}$ & Other \\
\hline$J 62-2\left(R_{390}\right)$ & $\begin{array}{l}\mathrm{J} 53 \\
{ }_{\mathrm{J}} 53(\mathrm{R} I d r d \mathrm{I} 6)\end{array}$ & $\begin{array}{l}4 \times 10^{-3} \\
2 \times 10^{-3}\end{array}$ & $20 / 20$ both present & $I \times 10^{-3}$ & $2 \times 10^{-5}$ \\
\hline & J53(RI44) & $5 \times 10^{-3}$ & $20 / 20$ both present & $8 \times 10^{-3}$ & $2 \times 10^{-3}$ \\
\hline & $\mathrm{J}_{53}(\mathrm{R} 269 \mathrm{~N}-\mathrm{I})$ & $2 \times 10^{-5}$ & o/Io both present & & \\
\hline & $\mathrm{J}_{53}\left(\mathrm{RP}_{4}\right)$ & $2 \times 10^{-3}$ & I8/20 both present & $1 \times 10^{-3}$ & $3 \times 10^{-5}$ \\
\hline & J53(S-a) & $3 \times 10^{-3}$ & $20 / 20$ both present & $3 \times 10^{-3}$ & $9 \times 10^{-5}$ \\
\hline & J53(RI5) & $2 \times 10^{-4}$ & $0 / 20$ both present & . & . \\
\hline
\end{tabular}

Method as given in Table 3. Both $\mathrm{R}$ factors were stable in each 'double'. From each 'double' R390 was transferred independently. R395, R396, R398 and R400, like R390, were transferred to J53(R/5) at reduced frequency compared with their transfer frequency to J53. RI 5 was eliminated by these factors from all clones tested.

were shown to be compatible (Table 7). In other experiments, not shown in Table 7, elimination of R46 by R394 occurred again. When R394 was transferred to J53 (R390) the 'doubles' carried kanamycin resistance (of R394) chloramphenicol and sulphonamide resistance (of $\mathrm{R} 390$ ), ampicillin resistance (of both factors) but not tetracycline resistance (a marker of $\mathrm{R} 390$ present in the recipient at mating). From this double, each plasmid was independently transferred, $\mathrm{R} 390$ without tetracycline resistance. In another mating in which R394 was transferred to J53 carrying the N plasmid, RI5, (selection being for kanamycin resistance) ampicillin resistance was lost from $\mathrm{R}_{394}$, but $\mathrm{R}_{1} 5$ was retained unaltered. Each plasmid was transferred independently from the 'double'.

When $\mathrm{R}_{394}$ was transferred to $\mathrm{J}_{53}(\mathrm{R} 4 \mathrm{OI})$ or $\mathrm{J}_{53}(\mathrm{R} 402)$ most kanamyin-resistant exconjugants had lost the resident plasmid. Where resistance genes of both plasmids were present there was evidence for recombination. All resistance markers were co-transferred in all matings and the markers of the temperature-sensitive plasmids, R4OI and R402 (see below) were stable during growth at $43^{\circ} \mathrm{C}$ (Table $6 d$ ). 


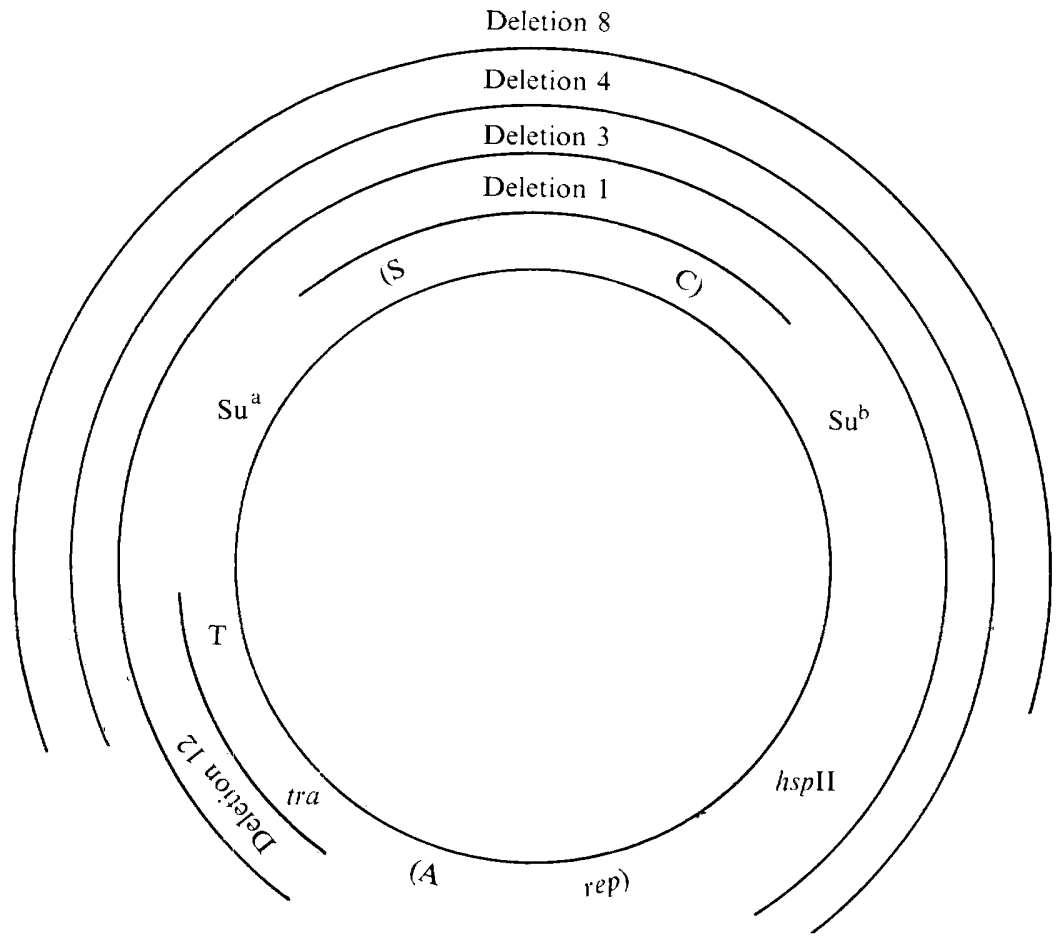

Fig. I. Deletion map of R390.

$\begin{array}{lccccc}\text { Segregant } & \text { Deletion } & \begin{array}{c}\text { Selected for } \\ \text { sensitivity to: }\end{array} & \begin{array}{c}\text { Transmis- } \\ \text { sibility }\end{array} & \text { hspII } & \begin{array}{c}\text { Drug } \\ \text { resistance }\end{array} \\ \text { R390-I } & \text { I } & \text { Chloramphenicol } & + & + & \text { ATSu } \\ \text { R390-2 } & 2 & \text { Chloramphenicol } & + & + & \text { ASTSu } \\ \text { R390-3 } & 3 & \text { Chloramphenicol } & + & - & \text { A } \\ \text { R390-4 } & 4 & \text { Chloramphenicol } & + & - & \text { A } \\ \text { R390-8 } & 8 & \text { Sulphonamide } & + & + & \text { A } \\ \text { R290-I } 2 & \text { I } 2 & \text { Tetracycline } & - & + & \text { ASCSu }\end{array}$

A genetic map of $\mathrm{R} 390$ is based on the properties of spontaneous segregants. It is assumed that all deletions arise by elimination of a single continuous segment (shown as arcs). Distances between genetic markers are arbitrary. Symbols: $\mathrm{Su}^{\mathrm{a}}$ and $\mathrm{Su}^{\mathrm{b}}$ are the two possible sites for the gene determining sulphonamide resistance. tra represents the genes determining transferability. rep genes are those necessary for replication of the plasmid.

$R 402$

R402 conferred resistance to ampicillin and streptomycin/spectinomycin. It co-existed stably with all standard $\mathbf{R}$ factors and with $\mathbf{R} 39 \mathrm{I}$. However, its replication was temperature sensitive (Table $6 d$ ). When $\mathrm{R}_{394}$ was introduced into $\mathrm{J}_{53}\left(\mathrm{R}_{402}\right)$ the resident plasmid was either eliminated or recombined with the incoming plasmid (Tables $7,6 d$ ).

\section{$R_{7} K$}

$\mathrm{R}_{7} \mathrm{~K}$ conferred resistance to ampicillin and a low level of resistance to streptomycin, but not spectinomycin. It could not be tested for $\mathrm{P}$ compatibility, since all known $\mathrm{P}$ plasmids confer ampicillin resistance and the level of streptomycin resistance determined by $\mathrm{R}_{7} \mathrm{~K}$ was too low for use in selection. It co-existed stably with plasmids of all other compatibility groups, except those of group W. Table 8 shows that it belonged to compatibility group W. 
Table 6. Effect of growth at $43^{\circ} \mathrm{C}$ on Rtsi, R40I, R394 and R402 and recombinant plasmids

(a) Colonies tested for resistance after $6 \mathrm{~h}$ growth in broth at $43{ }^{\circ} \mathrm{C}$ (evidence for recombination between $\mathrm{R}_{40 \mathrm{I}}$ and $\mathrm{Rts} \mathrm{I}$ )

$\begin{array}{cccccc} & \text { Total } & \mathrm{Sr}^{\mathrm{r}} & \mathrm{S}^{\mathrm{s}} \mathrm{K}^{\mathrm{s}} & \mathrm{S}^{\mathrm{r}} \mathbf{K}^{\mathrm{s}} & \mathrm{S}^{\mathrm{s}} \mathrm{K}^{\mathrm{r}} \\ \mathrm{J53} \text { (R40I/RtsI)* } & 49 & \text { II } & 38 & 0 & 0\end{array}$

(b) Colonies tested after growth overnight at $37{ }^{\circ} \mathrm{C}$ or $43{ }^{\circ} \mathrm{C}$

$\begin{array}{llll}\text { J62(R4OI) } & 37^{\circ} \mathrm{C} & 6 \mathrm{I} / 6 \mathrm{I} & \mathrm{A}^{\mathrm{r} S} \\ & 43^{\circ} \mathrm{C} & 6 \mathrm{I} / 64 & \mathrm{~A}^{\mathrm{s}} \mathrm{S}^{\mathrm{s}}: 3 / 64 \mathrm{~A}^{\mathrm{r}} \mathrm{S}^{\mathrm{r}} \\ \mathrm{J62}(\text { RtsI }) & 37^{\circ} \mathrm{C} & 57 / 58 & \mathrm{~K}^{\mathrm{r}}: \mathrm{I} / 58 \mathrm{~K}^{\mathrm{s}} \\ & 43^{\circ} \mathrm{C} & 6 \mathrm{I} / 6 \mathrm{I} & \mathrm{K}^{\mathrm{s}} \\ \mathrm{JS2}(\text { R40I/RtsI) } & 37^{\circ} \mathrm{C} & 62 / 62 & \mathrm{~S}^{\mathrm{r}} \mathrm{K}^{\mathrm{s}} \\ & 43^{\circ} \mathrm{C} & 63 / 63 & \mathrm{~S}^{\mathrm{s}} \mathrm{K}^{\mathrm{s}}\end{array}$

(c) Temperature sensitivity of R40I in hosts other than Escherichia coli. Colonies tested for resistance after overnight growth in broth at $37^{\circ} \mathrm{C}$ or $43{ }^{\circ} \mathrm{C}$ Klebsiella aerogenes $\mathrm{B} 9(\mathrm{R} 40 \mathrm{I})$

$$
\begin{array}{lcl}
37^{\circ} \mathrm{C} & 75 / 76 & \mathrm{~A}^{\mathrm{r}} \mathrm{S}^{\mathrm{r}}: \mathrm{I} / 76 \mathrm{~A}^{\mathrm{s}} \mathrm{S}^{\mathrm{s}} \\
43{ }^{\circ} \mathrm{C} & \mathrm{I} 25 / \mathrm{I} 25 & \mathrm{~A}^{\mathrm{s}} \mathrm{S}^{\mathrm{s}}
\end{array}
$$

Salmonella typhimurium $\mathbf{L T} 2(\mathrm{R} 40 \mathrm{I})$

$\begin{array}{lcl}37{ }^{\circ} \mathrm{C} & 45 / 45 & \mathrm{~A}^{\mathrm{r}} \mathrm{S}^{\mathrm{r}} \\ 43^{\circ} \mathrm{C} & 123 / 150 & \mathrm{~A}^{\mathrm{s}} \mathrm{S}^{\mathrm{s}}: 27 / 150 \mathrm{~A}^{\mathrm{r}} \mathrm{S}\end{array}$

(d) Stability of R394, R4OI and R4O2 and recombinants. Colonies tested after growth overnight at $43{ }^{\circ} \mathrm{C}$

\begin{tabular}{|c|c|c|c|c|c|}
\hline & Total & $\mathrm{A}^{\mathrm{r}} \mathbf{K}^{\mathrm{r}}$ & $\mathrm{A}^{\mathrm{r}} \mathrm{S}^{\mathrm{r}}$ & $\mathrm{A}^{\mathrm{r}} \mathrm{K}^{\mathrm{r}} \mathrm{S}^{\mathrm{r}}$ & $\mathrm{A}^{\mathrm{s}} \mathrm{K}^{\mathrm{s}} \mathrm{S}^{\mathrm{s}}(\mathrm{R}-)$ \\
\hline J53(R394) & 43 & 43 & . & . & 0 \\
\hline J53(R4OI) & 45 & . & 6 & . & 39 \\
\hline J53(R402) & 42 & . & 6 & . & 36 \\
\hline $\mathrm{J}_{53}\left(\mathrm{R}_{394} / \mathrm{R}_{40 \mathrm{I}}\right)$ & 44 & . & . & 43 & I \\
\hline J53(R394/R402) & $4 I$ & . & . & $4 r$ & 0 \\
\hline
\end{tabular}

* All three clones (see text) in which the kanamycin resistance of Rts I was retained on introduction of R40I behaved in the same way.

As with other members of this group there was little surface exclusion of related plasmids, but elimination of the resident plasmid (Hedges \& Datta, I97I).

\section{DISCUSSION}

All plasmids so far identified in the Proteus group have been $f i^{-}$, although $f^{+}$factors have been transferred to Proteus strains in various laboratories (Harada, Suzuki, Kameda \& Mitsuhashi, I960; Datta \& Hedges, I972a). No plasmids of the compatibility group which includes colIb-P9, R64 and RI44 (I-like plasmids) have been found in Proteus: I-like plasmids are not transmissible to the Proteus group (Datta \& Hedges, I972a). The lack of F-like and I-like plasmids is in marked contrast with the $\mathrm{R}$ factor sets observed in other genera. In Escherichia coli and Shigella spp. $f^{+}$factors are in the majority (Watson, I967; Meynell et al. 1968). In Salmonella spp. $f i^{-}$factors predominate, most of which are I-like (Meynell et al. I968 and unpublished data).

Which $\mathrm{R}$ factors one finds depends on the bacterial genera examined, not on geographical location. The $\mathrm{R}$ factors listed in Table 2 all (except $\mathrm{R} 7 \mathrm{~K}$ ) came from strains of Proteus 
Table 7. Transfer and compatibility of $R_{394}$

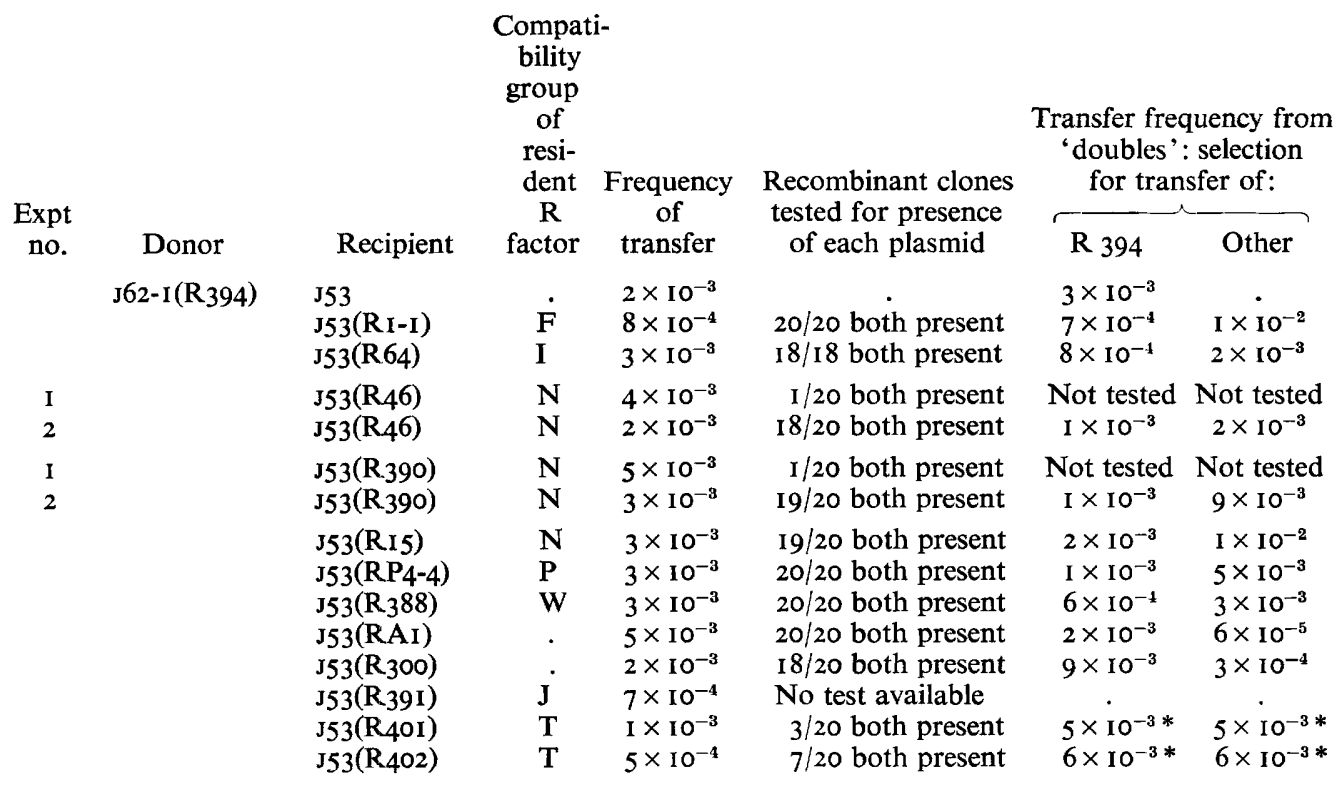

Methods as for Table 3. In Expt I, R394 appeared to have the compatibility properties of an N plasmid (although there was no exclusion). On retesting, R394 did not eliminate and did co-exist stably with N plasmids (but see text). Co-existance with all other plasmids was unaltered on retesting.

Each R factor (including those of group N, but excluding both R40I and R402) was transferred separately from 'doubles' with R394.

* Recipients from 'doubles' selected for R394, R40I, or R402 carried all resistances of both factors (20/20 clones tested from each selection).

Table 8. Transfer and compatibility of $R_{7} K$

$\begin{array}{cllc}\text { Donor } & \text { Recipient } & \begin{array}{c}\text { Frequency of } \\ \text { transfer }\end{array} & \begin{array}{c}\text { Recombinant clones tested } \\ \text { for presence of } \\ \text { each plasmid }\end{array} \\ \mathrm{J} 62-\mathrm{I}(\mathrm{R} 7 \mathrm{~K}) & \mathrm{J} 53 & 5 \times 10^{-3} & \\ & \mathrm{~J} 53\left(\mathrm{R}_{3} 88\right) & \mathrm{I} \times 10^{-3} & 0 / 20 \text { both present } \\ \mathrm{J} 53(\mathrm{~S}-\mathrm{a}) & \mathrm{J} 62-\mathrm{I} & 2 \times 10^{-4} & \\ & \mathrm{~J} 62-\mathrm{I}(\mathrm{R} 7 \mathrm{~K}) & \mathrm{I} \times 10^{-4} & 0 / 20 \text { both present }\end{array}$

Method as given in Table 3 .

rettgeri isolated in South Africa, but among South African Shigella strains, Watson (1967) found only $f^{+} \mathrm{R}$ factors. Plasmids of the N group (Datta \& Hedges, I97I) were the commonest among those described here. They carried resistance to chloramphenicol which had not previously been found on any $\mathbf{N}$ plasmid. This suggests that genes from $f^{+} \mathrm{R}$ factors have become incorporated into $\mathrm{N}$ plasmids: an example of recombination between an $\mathrm{N}$ and an F-like $\mathrm{R}$ factor is known. An $\mathrm{N}$ plasmid, R269 $\mathrm{N}$ (which confers resistance to ampicillin, streptomycin and tetracycline), acquired in the laboratory the determinant for kanamycin resistance from an $f^{+}$plasmid, R269 $\mathrm{F}$, present in the same culture (Hedges, 1972).

The penicillinases determined by $\mathrm{R}_{390}$ differed from that determined by $\mathrm{R} 46$, the prototype $\mathrm{N}$ plasmid. The penicillinase of $\mathrm{R} 46$ differs from most other $\beta$-lactamases in rapidly hydrolysing methicillin and cloxacillin (Datta \& Kontomichalou, I965) and oxacillin (Dale, I97I). Similar $\beta$-lactamases are determined by several other $N$ plasmids (R. W. Hedges, 
R. B. Sykes, P. Kontomichalou, N. Datta \& M. H. Richmond, unpublished) but the enzyme from $\mathrm{R} 390$ lacked this distinctive property.

R40I resembled RtsI in belonging to the same compatibility group, which we propose to designate $T$, and in that its replication was temperature sensitive. The temperature sensitivity of replication of a plasmid may be determined by the plasmid itself or the host chromosome (Jacob, Brenner \& Cuzin, 1964). Since the replication of R4OI was temperature sensitive in Escherichia coli, Salmonella typhimurium and Klebsiella aerogenes (Table $6 c$ ) the sensitivity was probably determined by the plasmid.

R394 also belonged to compatibility group T. Unlike other members of this group its replication was not temperature sensitive (Table $6 d$ ). This $\mathrm{R}$ factor gave initially confusing results in tests for compatibility since, with imperfect reproducibility, it dislodged resident $\mathrm{R}$ factors of the N group. However, R394 and N plasmids can stably co-exist and be transferred independently from 'doubles'. We have observed dislodgment of compatible $f^{-}$ $\mathrm{R}$ factors (including $\mathrm{N}$ plasmids) by Rts I (Hedges, unpublished). The mechanism of dislodgment is not known; perhaps 'repliconation' (Clark, I967) of T plasmids requires an enzyme, such as a recombinase, which interacts with other plasmids. The same mechanism may account for the deletion particular drug resistance genes in 'doubles' newly infected with R394.

$\mathrm{R} 402$ also belonged to the $\mathrm{T}$ compatibility group. Its replication was temperature sensitive (Table $6 d$ ). R402 was not identical with R4OI, since it conferred resistance to spectinomycin as well as to streptomycin and presumably therefore determined the production of streptomycin/spectinomycin adenylate synthetase, whereas R4OI presumably determined the synthesis of streptomycin phosphotransferase (Davies, Brezezinska \& Benveniste, I97I). Three of the I2 R factors from Proteus rettgeri belonged, like Rts I, to the T group. Rts I was derived from a strain Proteus vulgaris. Thus all T plasmids so far identified occurred in bacteria of the Proteus tribe.

$\mathrm{R} 7 \mathrm{~K}$ was compatible with all plasmids tested except $\mathrm{R}$ factor S-a (Hedges \& Datta, I97I) and R388 (Datta \& Hedges, I972 $b$ ), members of the W compatibility group.

The three R factors from Proteus rettgeri which did not belong to compatibility groups $\mathrm{N}$, $\mathrm{T}$ or W co-existed with our 'standard' plasmids and thus cannot be assigned to any defined group. We propose to designate $\mathrm{R}_{39}$ I as the prototype for a new group, J. R392 and R397 resemble $\mathrm{R}_{39 \mathrm{I}}$ in conferring resistance only to kanamycin and in having a low rate of transfer: we cannot test their compatibility with R39I.

Plasmids found in naturally occurring strains of the Proteus group thus seem to constitute a set significantly different from those found in Escherichia coli, Shigella or Salmonella spp.

We are grateful to Drs J. T. Smith and J. W. Dale for examining the penicillinase of R390, to Dr P. Kontomichalou for providing factor R ${ }_{7} \mathrm{~K}$ and to Dr M. Yoshikawa for Rtsi. J.N.C. is in receipt of grants from the South African Medical Research Council.

\section{REFERENCES}

BANnister, D. \& Glover, S. W. (I968). Restriction \& modification of bacteriophage by $\mathrm{R}^{+}$strains of Escherichia coli $\mathrm{K}$ I2. Biochemical and Biophysical Research Communications 30, 735-738.

Clark, A. J. (1967). The beginning of a genetic analysis of recombination proficiency. Journal of Cellular Physiology 70, Supplement I, I65-180.

Clowes, R. C. \& Hayes, W. (1968). Experiments in Microbial Genetics. Oxford and Edinburgh: Blackwell Scientific Publications.

DALE, J. W. (197I). Characterization of the $\beta$-lactamase specified by the resistance factor RI8I8 in E. coli K 12 and other Gram-negative bacteria. Biochemical Journal 123, 50I-505.

Datta, N. \& Hedges, R. W. (197I). Compatibility groups among $f-$ R factors'. Nature, London 234, $222-223$.

Datta, N. \& Hedges, R. W. (1972 a). Host ranges of R factors. Journal of General Microbiology 70, 453-460. 
Datta, N. \& Hedges, R. W. (1972 b). Trimethoprim resistance conferred by W plasmids in Enterobacteriaceae. Journal of General Microbiology. 72, 349-355.

Datta, N., Hedges, R. W., Shaw, E. J., Sykes, R. P. \& Richmond, M. H. (1971). Properties of an R factor from Pseudomonas aerogenes. Journal of Bacteriology 108, 1244-1 249.

Datta, N. \& Kontomichalou, P. (1965). Penicillinase synthesis controlled by R factors in Enterobacteriacea. Nature, London 208, 239-24I.

Datta, N. \& Kontomichalou, P. (I966). Transmissible R factors controllling penicillinase synthesis. Proceedings of the Ninth International Congress for Microbiology, pp. 22-23.

Davies, J., Brzezinska, M. \& Benveniste, R. (I97I). R factors, biochemical mechanisms of resistance to aminoglycoside antibiotics. Annals of the New York Academy of Sciences 182, 226-233.

Davis, J. E. Strauss, J. H. \& Sinsheimer, R. L. (I96I). Bacteriophage MS 2: another RNA phage. Science, New York $134,1427$.

Dennison, S. (1972). Naturally occurring R factor, derepressed for pilus synthesis, belonging to the same compatibility group as the sex factor $\mathrm{F}$ of Escherichia coli $\mathrm{K} \mathrm{I} 2$. Journal of Bacteriology 109, 5I6-422.

Doвоzy, A. \& HAMmer, H. (I968). Incidence of transmissible drug resistance in Proteus strains. Acta microbiologica Adademiae scientiarum hungaricae 15, I8 I-I 85 .

Falkow, S., Wohlmieter, J. A., Citarella, R. V. \& Baron, L. S. (1964). Transfer of episomic elements to Proteus. II. Nature of $\mathrm{lac}^{+}$Proteus strains isolated from clinical specimens. Journal of Bacteriology 88, I 598-I60I.

Frydman, A. \& Meynell, E. (1969). Interactions between derepressed F-like R factors and wild type colicin B factors: superinfection immunity and repressor susceptibility. Genetical Research 14, 31 5-332.

Harada, K., Suzuki, M., Kameda, M. \& Mitsuhashi, S. (1960). On the drug resistance of enteric bacteria. 2. Transmission of the drug resistance among Enterobacteriaceae. Japanese Journal of Experimental Medicine 30, 289-299.

Hedges, R. W., (1972). Phenotypic characterization of $f^{-} \mathrm{R}$ factors determining the restriction and modification hsp II specificity. Molecular \& General Genetics II5, 225-233.

Hedges, R. W. \& Datta, N. (197I). $f^{-}$R factors giving chloramphenicol resistance. Nature, London 234, 220-22I.

Hedges, R. W. \& DAtTA, N. (1972). Ri24, an $f^{+}$R factor of a new compatibility class. Journal of General Microbiology 7r, 403-405.

JACoB, F., Brenner, S. \& CuzIn, F. (1964). On the regulation of DNA replication in bacteria. Cold Spring Harbor Symposium in Quantitative Biology 28, 329-348.

JACOB, F. \& Wollman, E. L. (1954). Étude génétique d'un bactériophage tempéré d'Escherichia coli. I. Le système génétique du bactériophage $\lambda$. Annales de l'Institut Pasteur 87, 653-673.

Kontomichalou, P. (197I). R factors controlling resistance to the penicillins. Thesis, University of Athens.

Lawn, A. M., Meynell, E., Meynell, G. G. \& Datta, N. (I967). Sex pili and the classification of sex factors in the enterobacteriaceae. Nature, London 216, 343-346.

Meynell, E., Meynell, G. G. \& Datta, N. (1968). Phylogenetic relationships of drug resistance factors and other transmissible bacterial plasmids. Bacteriological Reviews 32, 35-83.

Mitsuhashi, S., Hashimoto, H., Egawa, R., TanaKa, T. \& Nagai, Y. (I967). Drug resistance of enteric bacteria. IX. Distribution of $\mathrm{R}$ factors in Gram negative bacteria from clinical sources. Journal of Bacteriology 23, I 242-I 245.

Naide, Y., Kawamura, T., Makino, K., Tamura, H. \& Watanabe, T. (1967). Prevalence of transferable drug resistance in drug resistant bacteria isolated from urinary tract infections in Japan. Japanese Journal of Microbiology $\mathbf{1 r}, 87-94$.

Odakura, Y., TANaka, T. \& MitsuHashi, S. (197I). Drug resistance and distribution of R factors among Proteus strains. Japanese Journal of Microbiology 15, 367-372.

Pitton, J.S. (1970). Controle génétique de la synthèse des penicillinases chez quelques bacilles Gramnégatifs. Pathologia et microbiologia 36, 299-300.

Poty, F., Goze, A. \& GaGnon, P. (I97I). Infectious resistance to carbenicillin in Proteus rettgeri: occurrence of two different penicillinases in the same strain. Journal of Antibiotics 24, 27I-272.

Smith, D. H. \& ARmour, S. E. (1966). Transferable R factors in enteric bacteria causing infection of the genito urinary tract. Lancet $\mathrm{ii}, \mathrm{I}$ 5-18

Terawaki, Y., TAKayasu, H. \& AKIBA, T. (1967). Thermosensitive replication of a kanamycin resistance factor. Journal of Bacteriology 94, 687-690.

Watson, C. E. (1967). Infectious drug resistance in Shigellae in Cape Town. South African Medical Journal 4I, 782-73I. 